\title{
Ageism Within Feminism
}

\author{
Joanne M. Pohl, Carol J. Boyd
}

Recently there has been a heightened interest in linking feminist theory and nursing science. However, neither feminists nor feminist nursing scholars have included aging women in their analyses. This paper analyzes liberal, radical and socialist feminist theories and discusses the gap within all three vis-a-vis aging women. A case is presented for including aging women within feminist thinking and recommendations for incorporating feminist theory and aging within the science of nursing are explicated.

[Keywords: ageism; feminism; women's issues]

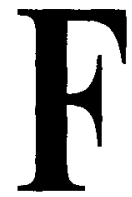
eminist theory, aging and nursing are concepts most often treated as discrete areas of knowledge, infrequently viewed as theoretically interrelated. Although there have been expanded efforts to bring feminist theory and nursing science together (Allen, 1985; Campbell \& Bunting, 1991; Chinn \& Wheeler, 1985; MacPherson, 1983; Meleis, 1990; Parker \& McFarlane, 1991), one must extrapolate when it comes to linking feminist theory with aging women. With the exception of Macdonald (1989, 1990; Macdonald \& Rich, 1983), Datan (1989), and Walker (1983), it appears that many feminists have relegated issues pertaining to aging women to others. At the same time, nurses have been actively involved with aging women in practice and research, yet their analyses of older women's health issues have generally not focused on structural gender inequities, and instead have dealt with health problems or issues from an individualistic, private model. Gerontological research in the past decade has increasingly documented gender specific issues of aging women as patient/client, caregiver and citizen (Abel, 1989, 1991; Brody, 1981; Hooyman, 1992; Horowitz, 1985; Pohl \& Warren, 1989; Pohl, Given, Collins \& Given, 1991; Robie, 1989; Stone, 1989). Only recently is feminist theory being used to guide analysis of one gerontological issuefamily caregiving (Abel, 1991; Hooyman, 1992; Pohl, Given, \& Given, 1991; Walker \& Allen, 1991).

The effects of demographic and economic trends in the past century have had major ramifications for aging women. Presently, 15.2 percent of women over 65 live below the poverty level. Thirty-five percent of African-American women and 25 percent of Hispanic women over 65 live below the poverty level. This is twice the rate for elderly men (Holden, 1989; Sidel, 1986). As part of the fastest growing segment of our society, women constitute 72.4 percent of the elderly poor. Moreover, the poverty rate for women 85 and older is 20 percent, a figure which approximates the poverty rate of children under 18 years (Lewis, 1985; Rice \& Feldman, 1983; Stone, 1989). Older women are increasingly disabled as they live longer, often living alone or in institutions (i.e., nursing homes or adult foster care homes). Although the rates of poverty have decreased over the past three decades, poverty rates have fallen more slowly and remain higher among females than males (Holden, 1989; Stone, 1989).

Aging women often represent powerful profiles in courage, although they frequently end up poor, disabled, invisible and alone, even after a lifetime of caring for other family members. Hence, as women age in this culture their powerlessness increases, an inevitable condition that is uncomfortable for women to face. Neither feminism nor nursing has fully embraced this reality.

In an effort to address ageism within feminism, we will review feminist theory within the context of aging women, the ramifications these theories have for nursing science and conclude with recommendations for incorporating theories of feminism and aging within nursing.

\section{History of Feminist Theory}

Marked by the Seneca Falls 1848 convention, a Victorian era feminism emerged during a period of notable economic and political change. Britain, France and the United States were adopting political systems of representative democracy. Prior to this time, women were guaranteed a certain status both in production (whether growing food or rearing children) and in government, although their social status was lower than that of men. Although industrialization opened up new opportunities for economic independence, by the turn of this century, women's cash contributions to their households were actually reduced to only 25 percent (Feree, 1991) resulting in less value given to their work at home and increased economic dependence on their husbands. This economic dependence has been institutionalized and still is evident in existing social policies (e.g., social security income). These political and economic changes altered women's situations and the way women perceived those situations.

Joanne M. Pohl, RN, PhD, Alpha Psi, is Assistant Professor, College of Nursing, University of Michigan. Carol J. Boyd, RN, PhD, Lambda, is Assistant Professor, University of Michigan. Correspondence to 2840

Norwich Road, Lansing, Michigan 48911.

Accepted for publication June 26, 1992. 
Since life expectancy was 47 years during the early 1900s, feminists took their issues to a population of women under 50 . However, contemporary demographic changes-caused by increased longevity and decreased fertility rates--are resulting in increasing numbers of older adults, most of whom are women, with fewer offspring. A female child born today can expect to live to be 78 ; if she lives to be 65 , she can expect to survive 19 more years to age 84 (Gibson, 1986; Haug \& Folmar, 1986; Lewis, 1985 ; Rice \& Feldman, 1983). As a result of this longevity, it is anticipated that there will be increasing numbers of disabled, elderly women; women who will live longer and need greater care (Manton \& Soldo, 1985). Unfortunately, feminist theory has not kept pace with the demographic changes within the new populations of women. Older women-outliving men by eight years; widowed for 15 years; if single, ending up in poverty and/ or nursing homes after years of providing care for their family members-remain invisible within feminist theories (Datan, 1989).

In order to address the long ignored issues relevant to aging women, three feminist positions, liberal, radical and socialist, will be reviewed as they relate to aging.

\section{Liberal Feminism}

Liberalism emerged with the growth of capitalism and proposed equal rights and opportunities for women relative to men and their rights and opportunities. The "equal to" always has been in relation to men. Liberal political theory assumes humans are essentially rational beings, and that "the fundamental moral values of liberalism are predicated on the assumption that all individuals have an equal potentiality for reason" (Jagger, 1988, p.33).

Liberal feminist views emerged out of liberal political theory. During the early 20th century women fought for such basic liberties as the right to vote and own property. Stressing equal opportunity for women, feminists fought within the context of such (liberal) values as individualism, privacy, equality, autonomy and self fulfillment (MacPherson, 1983). Liberal feminists (Mustin-Hare \& Marecek, 1990) have always opposed laws that do not grant the same equal social and economic opportunities to women as are granted to men. The major theme of liberal feminism has been the application of liberal principles to women (with men being the standard for comparison). This view continues to create an uncomfortable paradox. Liberal feminists imply that women can work to change gender discrimination; however, they simultaneously maintain that women currently have little power to change or control anything.

Predictably, science for the liberal feminist is based on the themes of rationality and individualism; the tradition of positivism fits liberal feminist thinking. As such, liberal feminists support "private" individualistic models. To approach issues of aging women from an individualistic (private) versus a collective (public) stance means that aging women are studied from a descriptive, rational, reductionistic model (leaving "biases" behind). There are those who take issue with the canon of objectivity and, in fact, find liberal feminism wanting because of this (Cook \& Fonow, 1990; Fox Keller, 1985; Jagger, 1988).
Liberal feminists might argue that decisions about reasonable treatment, long-term care, health expenditures for chronic diseases and income belong to the individual. There would be minimal need for public policy or community support services, except for those who couldn't protect themselves. The liberal feminist can argue that we are all rational beings: "It is a matter for the woman and her doctor." However, this "private" or "personal" argument is viewed by Meleis (1990) as relevant only for the privileged, and that many of the health-related decisions "foisted" on aging women occur because this group does not have the structural economic means to afford themselves a true choice. Liberal feminists have not addressed two major problems with their theory: 1) the mechanism by which one becomes powerful from a position of powerlessness; and 2 ) the process by which one can make a "free choice" when one does not have the necessary conditions to live out the choice. The resolution of these theoretical problems is critical.

Of the many feminist theoretical perspectives (e.g., liberal, radical, Marxist, socialist, etc.), liberal feminism probably has the closest link to nursing's history. Nurse researchers primarily have studied aging women from a reductionistic, rational, unbiased, private, individualistic and empirical model. Nursing (along with other social science disciplines) expects the findings from nursing research of aging women to be persuasive enough to alter the rational mind and thus cause changes in care and policy. Although there have been numerous studies on aging women from the discipline of nursing, the assumptions that a relatively powerless group of women can change the minds of those holding the health care dollars is never addressed by nursing.

\section{Radical Feminists}

Radical feminists emerged out of the 1960s and the women's liberation movement. Their unique contribution to feminism is their belief that the oppression of women is fundamental, within all types of economic systems and all cultures (McKinnon, 1989). Radical feminists argue that the liberal feminist's ideal of androgyny (equal mixture of female and male) is about as ridiculous as gluing a John Wayne and Brigitte Bardot together and is a form of "cheap grace" (Jagger, 1988). Compared to the liberal feminists, radical feminists emphasize the biological (sexual) differences that account for male dominance. A main weakness in radical feminist thought is that biology is viewed as independent of its environmental context, hence the body is not seen as changing and is not dealt with in the psychosocial, political and/or physical contexts of growing older.

Radical feminism is perhaps the least developed of the feminist perspectives and treats women as a monolithic group. As such, it is ahistorical, describing women's oppression as a universal experience. The radical feminist also tends to focus narrowly on women's control of their own bodies in sexual and procreative terms. Critics of radical feminism suggest this limited focus denies other realities (such as environmental and work hazards) to which women are often exposed. However, even these critics miss their own ageism. What does control of one's body mean at age 75 ? Certainly, it has nothing to do with procreation but a lot 
to do with a patriarchal system of health care where aging women will spend as much as 30 percent of their income on medical care (Muller, 1990; Sidel, 1986). They will be caught within a health care system that provides them with state-of-theart acute care, but few choices in terms of long-term care (Brody, 1990). The high technology of "health" care has the potential of becoming the ultimate in patriarchal control for aging women.

Radical feminists would question the liberal feminist goal of equality to men. Man is not the standard in radical feminism (MacKinnon, 1989). Radical feminists reject the dominant patriarchal (and liberal feminist) conception of knowledge as neutral, quantitative, value-free and objective. In fact, radical feminists accept the reliability of intuition as a special source of knowledge and consciousness raising as the methodology.

Radical feminist epistemology is committed to the view that the observer is inseparable from the observed, the knower from the known and that theory building is a social activity. In a sense, radical feminism is congruent with those who support "other ways of knowing" as authentic (Benner, 1984; Jacobs-Kramer \& Chinn, 1988; Leonard, 1989; Polyani, 1969; Schon, 1983; Wilkie, 1987) and Roger's concept of unitary beings (Rogers, $1970,1986,1990)$. For them, knowledge is not linear, but instead resembles a spiral in which humans always move and change and evaluate present and past positions from a new perspective.

Although criticisms of radical feminism include its narrow focus, it is probably the most parsimonious feminist theory of all since it reflects directly the experience of women and utilizes women's special ways of knowing. It also is congruent with some of the directions nursing scholars call for in knowledge building (Allen, 1985; Benner, 1984; Jacobs-Kramer \& Chinn, 1988; Meleis, 1990).

\section{Socialist Feminist Theory}

As an outgrowth of the women's liberation movement, social feminist theory is the newest of the feminist theories. This perspective tends to synthesize "the best insights of radical feminism and Marxist tradition" (Jaggar,1988, p.123) believing that human nature is created through biology, society, the physical environment and mediated by human labor (praxis). Socialist feminists (Chodorow, 1977; Ehrenreich \& English, 1973; Jaggar, 1988) take issue with liberal feminism and believe liberal feminist theory has fallen short on several accounts. For instance, rather than stress the application of liberal principles, socialist feminism claims that gender is socially constructed within rigid masculine and feminine dichotomies. Accordingly, these rigid gender structures have been historically important in maintaining male dominance by providing the framework for organizing the labor force, with women providing less valued services within the free market economic system. Hence, women's experience is shaped by gender, social class, race and nationality. However, despite socialist feminists' contention that women's oppression is shaped by many factors, age is not mentioned in the socialist feminist literature as a distinguishing component of women's experiences. This oversight, again, has relegated the aging woman to relative obscurity.
One of the major contributions of socialist feminist thinking has been to critique the distinction between private and public spheres that until now have been kept theoretically and politically separate. While liberal feminists have kept issues of the home as a private matter, socialist feminists contend that this position protects rape, incest and all forms of abuse by keeping them as private, not political, matters. The socialist feminist point of view suggests strategies are needed that strengthen individual capacities, reduce individual vulnerabilities (private or personal sphere) and provide for planned social change (Koss, 1990). Although the public-versus-private distinction is critical, socialist feminists have not discussed this distinction beyond the child rearing and parenting years.

Theoretically, a socialist feminist perspective could provide direction for the discipline of nursing since it allows nurses to consider aging women in their environmental context. It would allow nurses to attend to the critical questions relevant to aging women and bring those questions into the "public" arena where they belong. The questions of "choice" for aging women are very different than those of their younger counterparts. They are quality of life issues: where to live safely and how to pay for health care; where to receive quality home care as well as institutional care; whether to accept medical treatment and/or how to die with dignity. Feminists can no longer afford to ignore these women's issues, for in doing so, they keep the fastest growing segment of the American population invisible.

\section{Implications for Nursing Science and Art}

Feminist theory can fill a much needed gap in nursing. Historically, nursing has focused on the "individual;" however, socialist feminist theory suggests focusing on the individual is an incomplete view of the world and may be detrimental to those persons not included in the mainstream. Feminist theory would have us address self-care and health promotion, for example, not only in terms of the individual but in terms of the larger community and specific groups in that community, such as aging women. What does health promotion and primary care mean when you are 85 , disabled with arthritis, poor and widowed? Clearly health promotion must include immunizations and cancer screening, for example, but it must also address long-term care, community resources, appropriate living arrangements, reasonable treatment for a lingering chronic disease and the ending of treatment when there is no hope.

A key area in which nurses might begin to link feminist theory with aging women is in health policies and the inequities inherent in them. For example, discussions around national health plans are now actively under way. The existing system links health insurance to employment before retirement, and continues its emphasis on acute, high technology care after retirement. This has major consequences for women who are often in and out of the work force providing family care over a lifetime. They find in their old age that they must live with chronic diseases that don't kill, but linger and often disable (Verbrugge, 1984a, 1984b), requiring long-term care versus acute high technology care. A comprehensive health policy reflecting the needs of aging women would include a focus on prevention, rehabilitation, management 
of chronic diseases, humane long term care options as well as acute care. This policy would also acknowledge nurses as reimbursable providers, since nurses are often the most appropriate providers of care for these aging women (Harrington, Cassel, Estes, Woolhandler, \& Himmelstein, 1991).

In addition, nursing administrators ought to be concerned about family leave policies in their agencies. Leaves of absence for family care need to be available for both men and women caregivers. By recognizing informal family caregiving as a social good, administrators could develop programs and set policy that support and encourage women and men as both employees and caregivers. In addition, such policies would protect these middleaged women (and men) in their own aging if they are not penalized in pension plans for taking "time off" to provide care for family.

As nursing responds to the need for research in women's health (Blumenthal,1990; Koss, 1990), feminist theory will be critical in shaping the questions and the analyses of this agenda especially in examining aging women's health issues. Then nursing research will more likely be used for policy development and not just for individual private changes with a few clients. A feminist framework would have nurses confront the disparities within health care policy in the classroom, in practice, in research and in politics.

Feminist theory has far-reaching ramifications for nursing practice, theory development, research and especially policy. Gender sensitive practice, education and research by nurses as well as gender responsive policies need to account for differences between women's and men's experiences and confront those when they present clear risks for either gender.

\section{Conclusion}

When existing feminist theory is reviewed, the issues consistently concern women as workers, child bearers, mothers and wives. When choice, control and power are discussed, they are in terms of reproduction or marketplace economics. As an aging woman, Macdonald notes, "All my life in a man's world, I was a problem because I was a woman; now I am a problem in a woman's world because I'm a 65-year-old woman" (Macdonald, 1989, p.30). Macdonald (1989, 1990; Macdonald \& Rich, 1983) and Davis (1981) criticize feminists for ignoring those conditions which fall outside young, white, middle class experiences; in so ignoring these conditions, aging women have been ignored.

It is frightening for women to realize that their inevitable aging leads to increasing powerlessness in this culture, a condition that is difficult to dwell on, and thus has been ignored. Nursing has focused on the individual: Nurses "promote health" for the individual, theorize about "self-care," and continue to study the healthy, coping individual. The authors believe that nursing must pursue issues of aging women and explore them from feminist perspectives. Health may be a personal matter for persons of privilege (Meleis, 1990), but it is not for most aging women. The "bottom line" for using a feminist paradigm is to create and use knowledge for emancipation (Campbell \& Bunting, 1991).

There is a gap within feminist theory in terms of aging women, a gap nursing can fill. All nursing theory avoids language that objectifies the client/patient and stresses the role of the nurse as advocating for the client across the life span. However, nursing theory fails to explicate the reasons for the lack of parity within the system and as such, treats men and women as equal. Socialist feminism counters this assumption, thereby providing the discipline of nursing with a different perspective. It provides a useful and parsimonious framework for nursing as a discipline not only to understand aging women's health needs and concerns, but also to generate knowledge, research and policy that can be used to create alternatives to oppression. $\sqrt{\mathrm{Bg}} \mathrm{ET}$

\section{References}

Abel, E.K. (1989). Family care of the frail elderly: Framing an agenda for change. Women's Studies Quarterly, 17, 75-86.

Abel, E.K. (1991). Daughters caring for elderly parents. In J.F. Gubrium \& A. Sankar (Eds.), The home care experience: Ethnography and policy (189206). Newbury Park: Sage.

Allen, D.G. (1985). Nursing research and social control: Alternative models of science that emphasize understanding and emancipation. Image: Journal of Nursing Scholarship, 17, 58-64.

Benner, P. (1984). From novice to expert: Excellence and power in clinical nursing practice. Menlo Park, CA: Addison-Wesley.

Blumenthal, S.L. (1990). Proceedings of the symposia: Forging a women's health research agenda. Sponsored by National Women's Health Resource Center, Washington, DC, December 5 \& 6, 1990, February 28, 1991.

Brody, E.M. (1981). Women in the middle. The Gerontologist, 21, 471-480.

Brody, S.J. (1990). Critical policy issues in health and long-term care. In Z. Harel, P. Ehrlich \& R. Hubbard (Eds.), The vulnerable aged (223-247). New York: Springer.

Campbell, J.C., \& Bunting, S. (1991). Voices and paradigms: Perspectives on critical and feminist theory in nursing. Advances in Nursing Science, 13(3), 1-15.

Chinn, P.L., \& Wheeler, C.E. (1985). Feminism and nursing. Nursing Outlook, 33, 74-77.

Chodorow, N. (1977). Mothering: Psychoanalysis and the sociology of gender. Los Angeles: University of California Press.

Cook, J.A., \& Fonow, M.M. (1990). Knowledge and women's interests: Issues of epistemology and methodology in feminist sociological research. In J. McCarl Nielsen (Ed.), Feminist research methods: Exemplary readings in the social sciences (69-93). Boulder: Westview Press.

Datan, N.(1989). Aging women: The silent majority. Women's Studies Quarterly, 17(1-2), 12-19.

Davis, A. (1981). Class and race in the early women's rights campaign. In Women, race and class (47-69). New York: Vintage Books.

Ehrenreich, B., \& English,,D. (1973). Complaints and disorders: The sexual politics of sickness. Old Westbury, NY: The Feminist Press.

Feree, (1991). Beyond separate spheres: Feminism and family research. Journal of Marriage and the Family, 52, 866-880.

Fox Keller, E. (1985). Contending with a masculine bias in the ideals and values of science. The Chronicle of Higher Education, 31(5), 96.

Gibson, R.C. (1986). Blacks in an aging society. New York: Carnegie Corporation of New York.

Harrington, C., Cassel, C., Estes, C.L., Woolhandler, S., \& Himmelstein, D.U. (1991). A national long-term care program for the United States: A caring vision. Journal of the American Medical Association, 266, 3023-3029.

Haug, M., \& Folmar, S. (1986). Longevity, gender and life quality. Journal of Health and Social Behavior, 27 332-345.

Holden, K.C. (1989). Economic status of older women: A summary of selected research issues. In A.R. Herzog, K.C. Hoden, \& M.M. Seltzer (Eds.), Health and economic status of older women (92-130). Amityville, NY: Baywook.

Hooyman, N.R. (1992). Social policy and gender inequities in caregiving. In J.W. Dwyer \& R.T. Coward (Eds.), Gender, families, and elder care (181-201). Newbury Park: Sage.

Horowitz, A. (1985). Sons and daughters as caregivers to older parents: Differences in role performance and consequences. The Gerontologist, 25, 612-617.

Jacobs-Kramer, M.K., \& Chinn, P.L. (1988). Perspectives on knowing: A model of nursing knowledge. Scholarly Inquiry for Nursing Practice, 2, 129-144.

Jagger, A.M. (1988). Feminist politics and human nature. Totowa, NJ: Rowman $\&$ Littlefield. 
Koss, M.P. (1990). The women's mental health research agenda: Violence against women. American Psychologist, 45, 374-380.

Leonard, V.W. (1989). A Heideggerian phenomenologic perspective on the concept of the person. Advances in Nursing Science, 11(4), 40-55.

Lewis, M. (1985). Older women and health: An overview. Women and Health, 10, 1-16.

Macdonald, B., (1989). Outside the sisterhood: Ageism in women's studies. Women's Studies Quarterly, 17, 6-11.

Macdonald, B. (1990, July/August). Politics of aging: I'm not your mother. Ms.,56-58.

Macdonald, B., \& Rich, C. (1983). Look me in the eye: Old women, aging, and ageism. San Francisco: Spinsters, Ink.

MacKinnon, C. (1989). Toward a feminist theory of state. Cambridge, MA: Harvard University Press.

MacPherson, K.I. (1983). Feminist methods: A new paradigm for nursing research. Advances in Nursing Science, 5(2), 17-25.

Manton, K.G., \& Soldo, B.J. (1985). Dynamics of health changes in the oldest old: New perspectives and evidence. Milbank Memorial Fund Quarterly/ Health and Society, 63, 206-285.

Meleis, A.I. (1990). Being and becoming healthy: The core of nursing knowledge. Nursing Science Quarterly, 3(3), $107-114$.

Muller, C.F. (Ed.) (1990). The elderly. In Health care and gender (103-145). New York: Russell Sage Foundation.

Mustin-Hare, R., \& Marecek, J. (1990). Making a difference. New Haven: Yale University Press.

Parker, B., \& McFarlane,J. (1991). Feminist theory and nursing: An empowerment model for research. Advances in Nursing Science, 13(3), 59-67.

Pohl, J.M., \& Warren, B. (1989). Age related cancer screening practices of nurse practitioners. Poster presented at Gerontological Society of America's Annual Scientific Meeting, Minneapolis, MN.

Pohl, J.M., Given, B., \& Given, C.W. (1991). Adult daughters' transition to caregiving for their elderly disabled mothers. Paper presented at the meeting of the American Nurses Association's Council of Nurse Researchers, Nursing Research: Global Health Perspectives, Los Angeles, CA.

Pohl, J.M., Given, B., Collins, C., \& Given, C.W. (1991). Social vulnerability of daughters and daughters-in-law and the impact of parent care. Paper presented at the Second International Family Nursing Conference, Portland, OR.

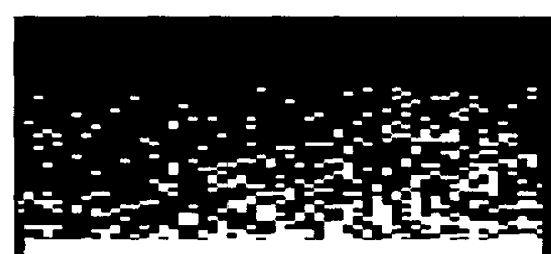

Become Master's prepared and specialize , in your choice of clinical areas as a Nurse in Anthropology and Business Administra-
Nursing avenues continue to expand as healthcare continues to change and grow. Since 1923, the internationally acclaimed Frances Payne Bolton School of Nursing at Case Western Reserve University has pioneered academic programs for those who seize healthcare's brightest opportunities.

\section{Advanced Practice/MSN Program} Midwife, Nurse Anesthetist, Nurse Practitioner (acute care, adult, family, geriatrics, pediatrics, neonatal, women's health, psychiatric mental health) or Clinical Nurse Specialist (community health, critical care medical/surgical, oncology). Dual degrees tion are also available.
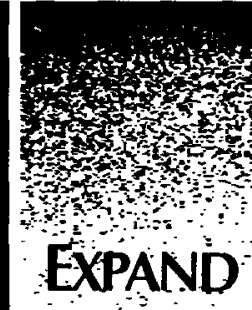

YOUR
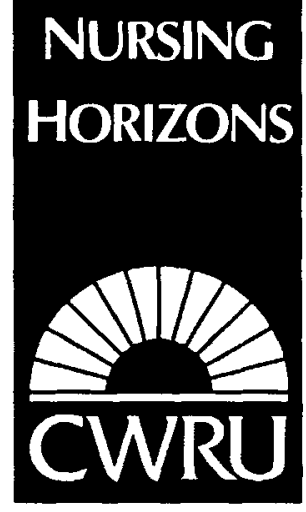

For information about enrolling in one of the country's foremost schools of nursing please contact: The Department of Student Services, School of Nursing, Case Western Reserve University, 10900 Euclid Ave., Cleveland, $\mathrm{OH}$ 44106-4904. (216) 368-2529. Toll-free 1-800-825-2540, ext. 2529.
Polyani, D. (1969). Knowing and being, (138-180). Chicago: University of Chicago Press.

Rice,D.P., \& Feldman,J.J. (1983). Living longer in the United States: Demographic changes and health needs of the elderly. The Milbank Quarterly, 61, 362-396.

Robie, P.W. (1989). Cancer screening in the elderly. Journal of the American Geriatrics Society, 37, 888-893.

Rogers, M.E. (1970). An introduction to the theoretical basis of nursing. Philadelphia: F.A. Davis.

Rogers, M.E. (1986). Science of unitary human beings. In V.M. Malinski (Ed.), Explorations on Martha Rogers' science of unitary human beings (3-8). Norwalk: Appleton-Century-Crofts.

Rogers, M.E., (1990). Nursing: Science of unitary, irreducible, human beings: Update 1990. In E.A.M. Barrett (Ed.), Visions of Rogers' science-based nursing (5-11). New York: National League for Nursing (Pub. no. 15-2285).

Schon, D. (1983). The reflective practitioner: How professionals think in action. New York: Basic Books.

Sidel, R. (1986). The special plight of older women. In Women and children last: The plight of poor women in affluent America. New York: Viking.

Stone, R.I. (1989). The feminization of poverty among the elderly. Women's Studies Quarterly, 17(1\&2), 20-34.

Verbrugge, L.M. (1984a). A health profile of older women with comparisons to older men. Research on Aging, 6, 291-322.

Verbrugge, L.M. (1984b). Longer life but worsening health? Trends in health and mortality of middle-aged and older persons. The Milbank Quarterly/Health and Society, 61, 475-519.

Walker, A. (1983). Care for elderly people: A conflict between women and the state. In J. Finch \& D. Groves (Eds.), A labour of love: Women, work, and caring (106-128). London: Routledge \& Kegan Paul.

Walker, A.J. \& Allen, K.R. (1991). A feninist analysis of positive outcomes of caregiving: Perspectives of elderly mothers and their daughters. Paper presented at the annual meeting of the National Council of Family Relations, Denver, November.

Wilkie, D. (1987). Hermeneutic research: Method congruent with the nursing perspective. In S. Gortner (Ed.), Nursing science methods (97-100). San Francisco: School of Nursing, University of San Francisco.

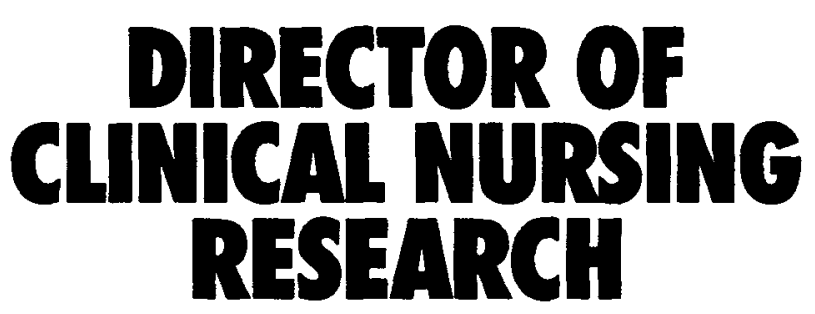

The University of Virginia Health Sciences Center in Charlottesville, Vinginia is looking for a qualified candidate to be responsible for guiding, supporting, and insuring the quality of clinical nursing research in the Health Sciences Center and for supporting and insuring the quality of the nursing components of multidisciplinary research. The Director will be responsible for developing the research skills and knowledge of advanced practice nursing clinicians and coaching and supporting junior faculty in the School of Nursing in their research efforts.

Experience in Nursing Research and a Ph.D. are required. Please call our nurse recruiter, Kendra May, for application information, at 1-800-THE-VA-RN. Or write: University of Virginia Health Sciences Center, Division of Nursing, Box 405, Charlottesville, VA 22908. EOE/AA.

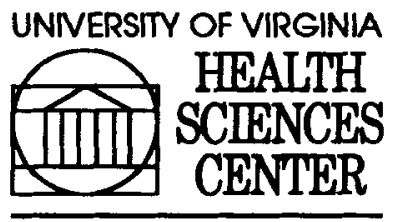

DNISION OF NURSING 